\title{
Preparation of $\mathrm{GaN}$ by alkoxide process using $\mathrm{Ga}\left(\mathrm{i}-\mathrm{OC}_{3} \mathrm{H}_{7}\right)_{3}$ as raw material
}

\section{$\mathrm{Ga}\left(i-\mathrm{OC}_{3} \mathrm{H}_{7}\right)_{3}$ を出発原料に用いたアルコキシド法による窒化ガリウムの合成}

\author{
TOmomi NAGAO, Yoichi ISHIMOTO and Jun-ichi MATSUSHITA
}

\author{
Department of Applied Chemistry, School of Engineering, Tokai University \\ 1117 Kitakaname, Hiratsuka 259-1292, Japan
}

TEL: 81-463-58-1211(ext.4186), FAX: 81-463-50-2012

( Received 15, November 1999 Accepted 2, March 2000 )

The Group-III nitrides have attracted much attention for applications of blue light emitters and high temperature electronic devices. The synthesis of single-phase gallium nitride (GaN) powder has been achieved by reacting gallium oxide or gallium triisopropoxide with ammonia $\left(\mathrm{NH}_{3}\right)$ flowing in a hot wall tube furnace.

Keywords: Gallium nitride, Alkoxide

\section{INTRODUCTION}

GaN 系半導体による高輝度青色系発光素子が開発され て以来、GaN の結晶成長技術が急速に進歩し、これにより 室温連続発振レーザーも開発されている。さらに、GaN 系 半導体は、ワイドバンドギャップ半導体として非常に魅力 的な物性值をもち、電子デバイスとして重要な材料である。 21 世紀に向けて省エネルギー対策が重要な問題になって いる。そして省電力化のひとつの対策として、電力変換に 伴う損失のさらなる低減が要求される。ワイドバンドギャ ップ半導体には、 GaN、AlN などのIII-V族窒化物半導体、

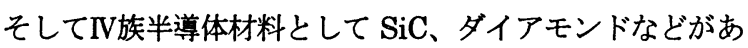
る。これらの材料はバンドギャップが大きいだけでなく、 原子間の結合距離が小さく、結合エネルギーが大きいため、 融点が高く、熱化学的に安定であり、ハードェレクトロニ クス材料とも呼ばれ、青〜紫色の短波長レーザーや大電力 超高電圧パワーエレクトロニクスデバイスなどへの応用が 可能である。そしてデータの記録密度を析違いに増加させ、 電力変換と輸送の高効率そして低損失化を通して、エネル ギー供給と環境問題の解決に貢献でき、かつ、先進的パワ 一エレクトロニクスシステムが構築可能である。耐熱、耐 振動の大出力高周波トランジスタが実現すると、日用家電 からモバイル・マルチメディア通信まで、さまざまな分野 での応用が可能となる。また、 GaN は全く無害な元素から できており、地球環境に優しいことも大きな魅力である。

そこで本研究では、スパッタ用ターゲット材料として、 従来高価であった $\mathrm{GaN}$ 粉末を安価に合成することを目的 として、(1) 出発原料として 3 酸化 2 ガリウム $\left(\mathrm{Ga}_{2} \mathrm{O}_{3}\right)$ を 用いる方法 (酸化物法) および (2) 出発原料にガリウムト リイソプロポキシド $\left(\mathrm{Ga}\left(\mathrm{i}-\mathrm{OC}_{3} \mathrm{H}_{7}\right)_{3}\right)$ を用いる方法 (アル コキシド法)の 2 種類により検討を行った。

\section{EXPERIMENTAL}

Figure 1 に、本研究で用いた合成装置図を示す。マスフ ローコントローラーを用いて制御したアンモニアガスまた は窒素ガスを、電気炉に設置された石英反応管内に導入し、 原料と反応させる装置である。過剩のアンモニアガスは、 反応管から接続されている硝酸バブラーにて吸収される。

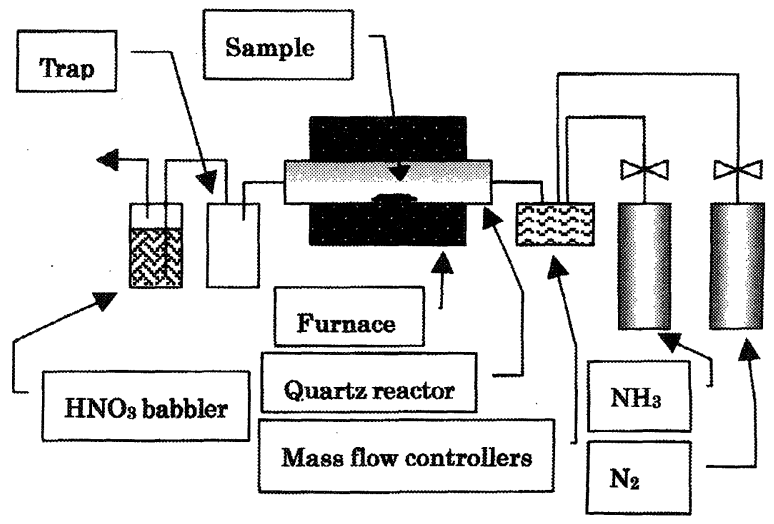

FIG.1. Apparatus for synthesis of $\mathrm{GaN}$ powder.

Figure 2 に、本研究で用いた酸化物法とアルコキシド法 による $\mathrm{GaN}$ の合成手順を示す。原料には、 $\mathrm{Ga}_{2} \mathrm{O}_{3}$ (フルウ チ化学製)、 $\mathrm{Ga}\left(\mathrm{i}-\mathrm{OC}_{3} \mathrm{H}_{7}\right)_{3}$ (トリケミカル研究所製)、アンモ ニアガス (昭和電工製)、室素ガス (日本酸素製)を用いた。 試料を設置した石英反応管を、窒素気流下、473 K、0.5 h 乾燥後、アンモニアガスに切りかえ、所定の温度にて $1 \mathrm{~h}$

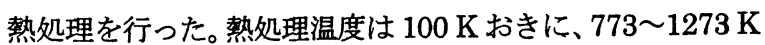
の温度とした。原料に $\mathrm{Ga}\left(\mathrm{i}-\mathrm{OC}_{3} \mathrm{H}_{7}\right)_{3}$ を用いた場合は、アル コキシル基の熱分解が $723 \sim 773 \mathrm{~K}$ の温度で起こるため、 $773 \mathrm{~K}$ にて $1 \mathrm{~h}$ 保持し、熱分解して残留している炭素を炭化 


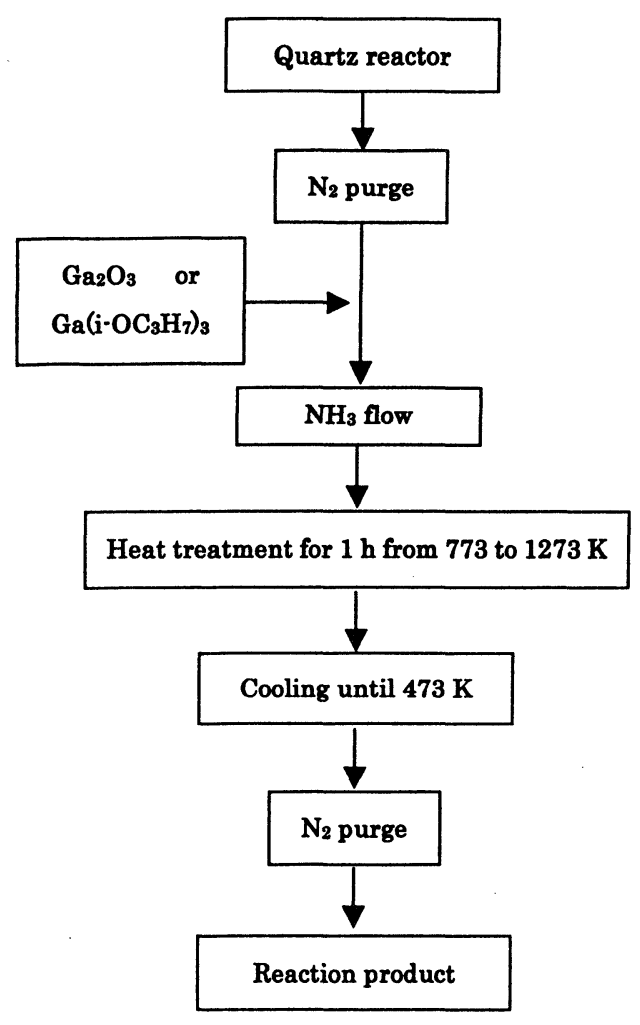

FIG.2. Schematic diagram of preparation for $\mathrm{GaN}$.

水素に転化させ、反応系外に放出する手順を用いた。原料 に $\mathrm{Ga}_{2} \mathrm{O}_{3}$ を用いた場合は、所定の温度にて $1 \mathrm{~h}$ 熱処理を行 った。どちらの原料を用いた場合についても、所定の時間 の熱処理終了後は、 $473 \mathrm{~K}$ までアンモニア気流下にて放冷 後、ふたたび窒素に切りかえ、室温まで放冷して生成物の 取り出しを行った。

\section{RESULTS AND DISCUSSION}

Figure 3 および 4 に、それぞれ酸化物法およびアルコキ シド法により合成した生成物の、X 線回折分析法による結晶 相の同定結果を示す。どちらの場合も、1073 K から窒化が 始まり、1173 K では酸化物のピークは消滅した。得られた 生成物は、1173 K 以上の温度で熱処理した試料では淡黄色 粉末であったが、それ以外の温度で熱処理した試料では白 色粉末であった。アルコキシド法では、 $873 \mathrm{~K}$ 以下の温度 での熱処理では、XRD パターンがアモルファスであること を示した。 $1273 \mathrm{~K}$ 熱処理試料においては、酸化物法とアル コキシド法いずれの場合も、 $\mathrm{GaN}$ 単相を示した。

\section{CONCLUSION}

酸化物法およびアルコキシド法いずれの方法においても、 熱処理温度 $1173 \mathrm{~K}$ で GaN 単相を示し、従来の酸化物法と

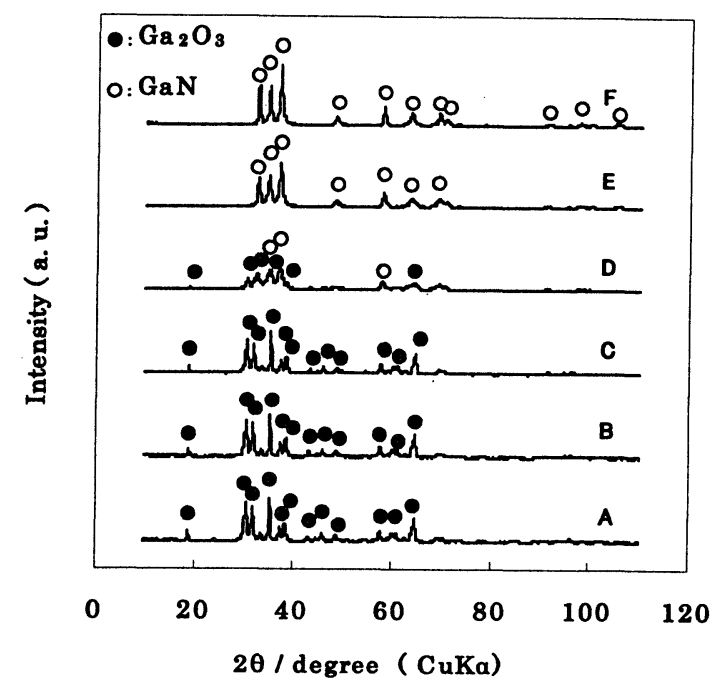

FIG.3. $X$-ray diffraction patterns of $G a N$ synthesized by using reaction of $\mathrm{Ga}_{2} \mathrm{O}_{3}$ and $\mathrm{NH}_{3}$.

$A: 773 \mathrm{~K}, \mathrm{~B}: 873 \mathrm{~K}, \mathrm{C}: 973 \mathrm{~K}, \mathrm{D}: 1073 \mathrm{~K}, \mathrm{E}: 1173 \mathrm{~K}$, $\mathrm{F}: 1273 \mathrm{~K}$

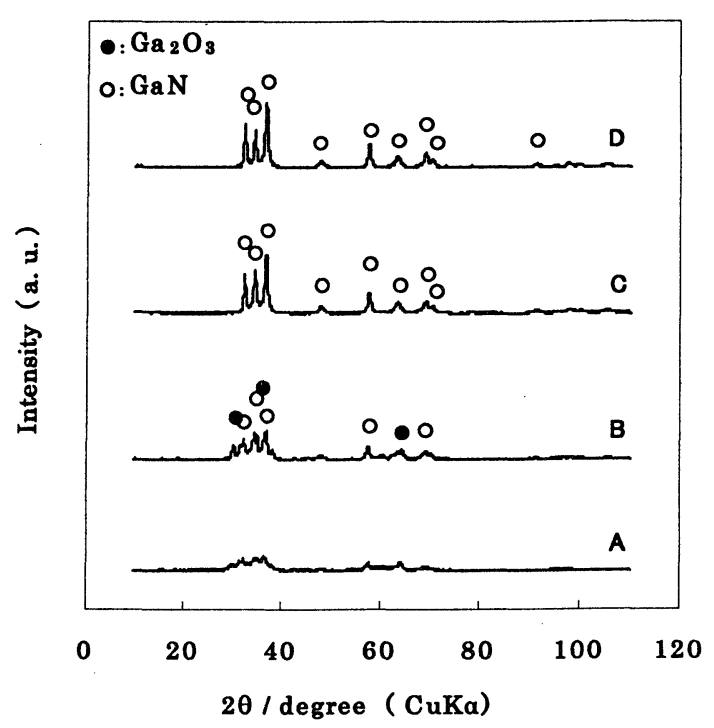

FIG.4. X-ray diffraction patterns of $\mathrm{GaN}$ synthesized by using reaction of $\mathrm{Ga}\left(\mathrm{i}-\mathrm{OC}_{3} \mathrm{H}_{7}\right)_{3}$ and $\mathrm{NH}_{8}$.

A : $973 \mathrm{~K}, \mathrm{~B}: 1073 \mathrm{~K}, \mathrm{C}: 1173 \mathrm{~K}, \mathrm{D}: 1273 \mathrm{~K}$

同様に、今回初めて $\mathrm{Ga}\left(\mathrm{i}-\mathrm{OC}_{3} \mathrm{H}_{7}\right)_{3}$ を用いて $\mathrm{GaN}$ の合成が 可能であることが明らかになった。

\section{REFERENCE}

1 C. M. Balkas, C. Basceri and R. F. Davis, Powder Diffraction, 10, 266 ( 1995 ).

Presented at '99 SAS Intelligent Symposium 